\title{
Experiencing 'flow' in jazz performance
}

\author{
Elina Hytönen- $\mathrm{Ng}$ \\ Burlington, VT: Ashgate; 2013 \\ ISBN: 978-1-4094-4790-0 (HB)
}

\author{
Andrew W. Hurley \\ University of Technology, Sydney \\ Andrew.Hurley@uts.edu.au
}

This short but informative volume sheds light on an otherwise under-illuminated aspect of jazz performance, namely on what the author calls 'flow'; those fleeting moments where musicians feel that their music-making clicks in a special way. Typically, musicians report paradoxical feelings of loss of control, but an effortless gain in mastery, as well as a sense of grace and elation. There are several inadequate names for this ineffable, highly subjective experience: 'Into the zone', 'cooking', 'chemistry' (Hytönen-Ng 2013), and 'magic moments' (Jeddeloh, 2003) being a few of them. It can be experienced in solo play, but most often in conjunction with sympathetic musicians. Hytönen- $\mathrm{Ng}$ considers that the experience is a universal - if still comparatively rare - one in western contemporary jazz, but she suggests that it can also be experienced by musicians performing in other genres too.

The book is based on a series of semi-structured interviews Hytönen- $\mathrm{Ng}$ conducted during the 2000s with eighteen jazz musicians from Finland, the United States, Britain, and Australia. She has coaxed them to talk about something that is rarely discussed, especially with non-band members. Hytönen- $\mathrm{Ng}$ reads these musicians' discourse against the literature as it relates to jazz improvisation and to talk about improvisation (Monson 1996; Berliner 1994, 1997) but also - and this is her methodological innovation - in accordance with the psychological literature relating to flow, or peak, experiences, such as Maslow $(1971,1987)$ and Csikszentmihalyi $(1994,2002)$. Much of what Hytönen-Ng's informants say about being in flow coincides with the descriptions of these peak moments, that, according to Maslow, are often the domain of so-called 'self-actualising', a creative and fulfilled individuals (Maslow 1968).

Hytönen- $\mathrm{Ng}$ approaches jazz flow from a range of useful perspectives. These relate to, for example, the management of balancing and existential need for the flow moment and the material need to treat music as a source of income; the often collective context of flow; the links between flow and a spiritual outlook (or, even, an atheistic one); the importance of audience and venue to the experience; as well as a miscellany of other factors, such as whether it translates to recordings, whether it is more likely in a large or small setting, and what alcohol and drug use may be effective in achieving flow, and in what quality of experience. Hytönen- $\mathrm{Ng}$ argues for the concept of flow, while pointing out that her informants enunciate their views in a context that has its own ways of talking about, mythologizing and masculinizing jazz. She thereby touches on gender- 
based, cultural and historical factors and how these impact on what we might call 'flow talk', that is the ways in which jazz practitioners and audiences talk about 'flow'. For example, the author explains well why Finnish musicians might be indisposed to spiritual, explanations of higher power: Because of their educational and Protestant work ethic background, they prefer more rational approaches that bolster the importance of professionalism and agency. Cultural dimensions like these are areas that could be explored in greater detail, although admittedly, the scope of Hytönen- $\mathrm{Ng}$ study militated against a full exploration of such aspects: She was only able to interview two women, for example. Still, I would be interested to know more about how flow talk might manifest itself differently in other cultural settings, including the AfricanAmerican one.

In the concluding chapter, Hytönen-Ng's hypothesis emerges in full: Flow moments in western jazz performance are akin to both trance and meditative states and offer a moment of "profane or secular transcendence" in a secular world (153). For the author, this is very much a spiritual moment, even if her informants may not refer to it as such: "In Western countries flow offers a socially acceptable way to connect with the unconscious and spiritual realm at the same time as major religions are losing their hold on the collective imagination" (155). I expect that Hytönen-Ng's study will prove controversial, perhaps even with some of her informants like those Finnish musicians who eschewed mysticising the flow moment. As she points out herself, nothing divides the jazz community more than questions of religion and spirituality. But the book is essential reading for those who are interested in how musicians can get hooked on jazz performance and in why many jazzers have proven to be so interested in things like meditation, Eastern religions, and altered states of consciousness. Hytönen-Ng's work suggests that spirituality might be more core to the contemporary jazz experience than many would admit. In line with the thrust of some of the psychological literature she draws on, her study also indicates how musicians might best go about accessing 'the zone'. Hytönen-Ng's perceptive and insightful book about contemporary jazz discourse can also complement an analysis of how flow talk in jazz has changed over time, with the rise, fall and rise again of the spiritual jazz genre, for example. It can also pave the way for the analysis of why parts of the jazz scene have been critical of jazz as spirituality.

\section{References}

Berliner, Paul -

(1994) Thinking in Jazz: The Infinite Art of Improvisation. Chicago: University of Chicago Press.

(1997) 'Give and Take: The Collective Conversation of Jazz Performance.' In R. Keith Sawyer, ed., Creativity in Performance. Greenwich, CT: Ablex, 9-41.

Csikszentmihalyi, Mihaly -

(1994) The Evolving Self: A Psychology for the Third Millennium. New York: HarperCollins.

(2002) Flow: The Classic Work on How to Achieve Happiness. London: Rider.

Jeddeloh, Steven C. (2003) 'Chasing Transcendence: Experiencing 'Magic Moments”

in Jazz Improvisation.'P.h.D. Thesis, Fielding Graduate Institute.

Maslow, Abraham H. -

(1971) The Farther Reaches of Human Nature. New York: Viking Press.

(1987) Motivation and Personality. New York: HarperCollins.

(1968) Towards a Psychology of Being. New York: Van Nostrand, 71.

Monson, Ingrid (1996) Saying Something: Jazz Improvisation and Interaction. Chicago: University of Chicago Press. 